\title{
Assessment of AFLP-based Genetic Relationships among Date Palm (Phoenix dactylifera L.) Varieties of Iraq
}

\author{
Jaladet M.S. Jubrael ${ }^{1}$ \\ IPA-Agricultural Research Center, Abu-Ghraib, Baghdad, Iraq \\ Sripada M. Udupa and Michael Baum² \\ International Center for Agricultural Research in the Dry Areas (ICARDA), P.O. Box 5466, Aleppo, \\ Syria
}

\begin{abstract}
AdDitional INDEX wORDs. genetic distance, genotypic diversity, molecular characterization, varietal identification
Abstract. Currently, the identification and characterization of date palm varieties rely on a small number of morphological traits, mainly of fruit, which are complex and greatly influenced by the environment. As a result, different varietal names may actually refer to the same variety while different varieties may have the same name. Therefore, new descriptors like molecular markers are required to identify, characterize, and estimate genetic diversity in this crop. Here we used amplified fragment length polymorphism (AFLP) markers to discriminate 18 Iraqi date palm varieties and to estimate the genetic relationship among the varieties. A total of 122 polymorphic AFLP loci were scored, with an average of 17.4 polymorphic loci per primer combination. The use of any one of the four combinations, P101(aacg)/ M95(aaaa), P74(ggt)/M95(aaa), P73(ggg)/M95(aaa), or P100(aacc)/M95(aaaa), was sufficient to uniquely identify all the varieties. Jaccard's genetic similarity index ranged from 0.108 to 0.756 , indicating moderate to diverse relationships. Estimation of average proportion of fixed recessive AFLP loci indicated that most of the loci in variety 'Chipchab' were fixed, whereas most of the loci in 'Jamal Al-Dean' could be heterozygous and in-between in other varieties. Unweighted pair group method with arithmatic mean (UPGMA) analysis ordered the date palm varieties first into two broad groups at $27 \%$ similarity levels. One group consisted of seven varieties and the second group consisted of the remaining 11 varieties of date palm. These results showed that the AFLP technique is an efficient method for varietal identification and estimating genetic relationships in date palm.
\end{abstract}

Date palm $(2 \mathrm{n}=2 \mathrm{x}=36)$ is one of the oldest fruit trees cultivated by mankind and is mentioned in holy books such as the Bible and Qur'an. Date palm is a dioecious, perennial monocot plant that is commercially important in the Middle East and North Africa, and it is valued for its social, religious, and agricultural value in this region. In addition to producing a valuable dessert fruit, parts of the tree are used for shelter, fuel, and making handicrafts, rendering it a significant earner of revenue for both small and large farmers. The date palm also makes a significant contribution toward the creation of equable microclimates within the fragile oasis ecosystems, thus enabling sustainable agricultural development in many drought- and saline-affected regions (Barreveld, 1993).

For centuries, the vegetative propagation of date palms by offshoots was the only commercial method available to multiply the best varieties. These offshoots are produced from axillary buds situated on the base of the trunk of the juvenile palm. Offshoots develop slowly and their numbers are limited since they are only produced during a certain stage of the tree's lifetime. The low number of transplantable offshoots varies from 10 to 30 depending on the variety and the cultivation practices used.

Received for publication 10 Sept. 2004. Accepted for publication 24 Nov. 2004 The authors' research was supported by grants from the Arab Fund for Economic and Social Development (AFESD, Kuwait) and the German Federal Ministry of Economic Cooperation and Development (BMZ, Bonn, Germany). We thank Aman Sabbagh for excellent technical assistance.

'Present address: Department of Biology, College of Science, Duhok University, Duhok, Iraq.

2To whom reprint requests should be addressed.E-mail address: M.Baum@cgiar. org
The exact origin or gene center of the date palm has been lost. However, there seems to be a consensus that the date palm originated in the area stretching from northeast Africa into the delta of the Euphrates and Tigris (Barreveld, 1993). Some even believe that the crop originated in Iraq (Al-Khalifah and Askari, 2003). Evidence of date palm cultivation in Iraq goes as far back as $4000 \mathrm{BC}$ during Mesopotamian civilization in what is now known as Babel in southern Iraq.

Before 1991, Iraq was the largest producer of dates in the world (Food and Agriculture Organization, 2004) and had the largest date "forest" in the world, on the Fao Peninsula (MacFarquhar, 2003). However, during the Gulf and Iran-Iraq wars, many palm trees were destroyed and more died when the southern marshes were drained. Wars and sanctions have negatively affected both the production and natural genetic diversity of the crop in Iraq and inhibited the much-needed impetus to rebuild the date palm industry. For instance, the population of 16 million date palm trees around Basra before the wars was reduced to around 3 million in 2003 (MacFarquhar, 2003) and might have resulted in genetic erosion in the natural population. Development of suitable DNA molecular markers for this crop may allow the researchers to estimate genetic diversity and genetic erosion, which will ultimately aid in the genetic conservation of date palm.

Despite its economic and social importance, little research has been undertaken on genetic characterization of date palm germplasm and varieties. Information on germplasm characterization is important for varietal identification, genetic conservation, and breeding of this crop. In particular, it is often useful to plant genetically diverse varieties in combinations to avoid genetic vulnerability to various biotic stresses and also to identify diverse 
parental combinations to create segregating progenies with genetic variability that would provide further gain from selection and for molecular mapping.

Various molecular marker systems, such as isozymes, restriction fragment length polymorphisms (RFLPs), random amplified polymorphic DNAs (RAPDs), andAFLPs, had been tested for their applications in date palms (Bennaceur et al., 1991; Corniquel and Mercier, 1994; Devanand and Chao, 2003). Among the marker systems tested, AFLP markers (Vos et al., 1995) are particularly useful since they allow genetic diversity to be assessed at a large number of loci without prior sequence knowledge, and data are obtained quickly and reproducibly (Barrett and Kidwell, 1998; Powell et al., 1996; Sanchez et al., 1999; Tohme et al., 1996). This technique combines the restriction site recognition element of RFLP analysis with the exponential amplification aspects of polymerase chain reaction (PCR)-based markers, providing a less labor intensive, yet more robust compromise between the two basic marker types (Lin et al., 1996; Powell et al., 1996). In date palm and in various other plants, AFLP technique provided useful information regarding genetic relationships and genetic diversity (Bandelj et al., 2004; Devanand and Chao, 2003; Fanizza et al., 2003; Herselman, 2003). Here we use AFLP technique for varietal identification and genetic characterization of 18 important date palm varieties of Iraq.

\section{Materials and Methods}

Plant materials. Young leaves from the 18 well-defined reference date palm varieties were collected for DNA extraction from the date palm farm, Ministry of Agriculture, Al-Latifia, Iraq. The varieties collected were 'Barhi', 'Um Al-Dihen', 'Usta Umran', 'Maktom', 'Guntar', 'Khestawi,' 'Zahdi,' 'Sakri,' 'Khedrawi', 'Chipchab', 'Ashrasi', 'Jamal Al-Dean', 'Shwethi Asfar,' 'Zuber', 'Bint Al-Suda', 'Bream', 'See Sandali', and 'Tebarzal'. Since commercial date palm varieties are asexually propagated in commercial farms and varieties used in this study were reference varieties, we assumed that the population was homogeneous. Therefore, only one plant from each variety was selected for AFLP analysis. A detailed background of these varieties, including their fruit characteristics, is available in Mohammed et al. (1983).

DNA extraction. Around 2-3 g of leaf tissue was ground to a fine powder using liquid nitrogen. Twelve milliliters of hot $\left(60{ }^{\circ} \mathrm{C}\right) 2 \mathrm{x}$ CTAB extraction buffer (2\% CTAB, $1.4 \mathrm{M} \mathrm{NaCl}, 0.1$ м Tris- $\mathrm{HCl} \mathrm{pH} 8,20$ mm EDTA, and 0.2\% ß-mercaptoethanol) were added, mixed well, and incubated at $60{ }^{\circ} \mathrm{C}$ in a water bath. After $30 \mathrm{~min}$ of incubation at $60{ }^{\circ} \mathrm{C}$ with gentle swirling, the resulting cell lysate was extracted with an equal volume of chloroform/isoamylalcohol $(24: 1, \mathrm{v} / \mathrm{v})$. The cell lysate was then centrifuged (at $8000 g_{\mathrm{n}}$ and $20^{\circ} \mathrm{C}$ for $20 \mathrm{~min}$ ). The aqueous phase was transferred into another tube and precipitation occurred with the addition of 0.66 volume of isopropanol. The precipitate was then collected by centrifugation (at $8000 \mathrm{~g}_{\mathrm{n}}$ and $20^{\circ} \mathrm{C}$ for $20 \mathrm{~min}$ ). Pellets were washed with $70 \%$ ethanol, dried, and then dissolved overnight at $4{ }^{\circ} \mathrm{C}$ in $1 \mathrm{~mL}$ of TE buffer (10 mM Tris- $\mathrm{HCl}, \mathrm{pH} 8.0$, 1 mM EDTA).

AFLP Analysis. AFLP analysis was carried out by following the method of Vos et al. (1995), with few modifications. One microgram of genomic DNA from each variety was digested for $3 \mathrm{~h}$ at $37^{\circ} \mathrm{C}$ with $5 \mathrm{U}$ each of two restriction enzymes, Tru9I (recognition site: $5^{\prime} \mathrm{T} \downarrow$ TAA $3^{\prime}$ ) and PstI (recognition site: $5^{\prime} \mathrm{CT}$ GCA $\downarrow \mathrm{G} 3^{\prime}$ ), in $40 \mu \mathrm{L}$ final volume of reaction mix containing 1x one-phor-all buffer (Pharmacia Biotech, Uppsala, Sweden).
After the digestion, the specific adapters were ligated to the restricted DNA fragments by adding $10 \mu \mathrm{L}$ of a solution containing 50 pmol of Tru9I-adaptor and 5 pmol of PstI-adaptor, $1 \mathrm{U}$ of $T_{4}$ DNA-ligase, $1 \mathrm{~mm}$ rATP in $1 \mathrm{x}$ one-phor-all buffer. The incubation was continued for $3 \mathrm{~h}$ at $37^{\circ} \mathrm{C}$. After the ligation, the reaction mixture was diluted to 1:5 using sterile distilled water. Preselective PCR amplification was performed in a reaction volume of 20 $\mu \mathrm{L}$ containing $50 \mathrm{ng}$ of each of the two oligonucleotide primers (P00 and M00) corresponding to the Tru9I and PstI adaptors, 2 $\mu$ L template-DNA, 1 U Taq DNA polymerase and 1x PCR buffer (Roche, Mannheim, Germany). Amplifications were performed in a thermocycler (PE 9600) programmed for 30 cycles, each cycle comprising $30 \mathrm{~s}$ at $94{ }^{\circ} \mathrm{C}, 1 \mathrm{~min}$ at $60{ }^{\circ} \mathrm{C}$, and $1 \mathrm{~min}$ at $72^{\circ} \mathrm{C}$. The preamplification product was diluted to $1: 5$ and $2 \mu \mathrm{L}$ used as a template for selective amplification. Selective amplification was conducted using Tru9I and PstI primer combinations listed in Table 1. Amplifications were performed in a thermocycler (PE 9600) programmed for 36 cycles with the following cycle profile: a 30-s DNA denaturation step at $94{ }^{\circ} \mathrm{C}$, a 30 -s annealing step (see below), and a $1-$ min extension step at $72{ }^{\circ} \mathrm{C}$. The annealing temperature was varied: in the first cycle it was $65^{\circ} \mathrm{C}$; in each subsequent cycle for the next 12 cycles it was reduced by $0.7^{\circ} \mathrm{C}$ (touchdown PCR), and for the remaining 23 cycles, it was $56^{\circ} \mathrm{C}$. The selective amplification products were loaded onto $6 \%$ denaturing polyacrylamide gels, and DNA fragments were visualized by silver staining using a silver staining kit (Promega, Madison, Wis.) as described by the supplier. Silver-stained gels were scanned to capture digital images of the gels after air drying.

Data Analysis. Positions of scorable AFLP bands were transformed into a binary character matrix (" 1 " for the presence and " 0 " for the absence of a band at a particular position); only polymorphic bands were used in the analysis. Jaccard's similarity index (Jaccard, 1908) between any pairs of varieties was determined. The Jaccard similarity matrix was used for the cluster analysis (UPGMA) to study the genetic relationships among the varieties. Jaccard's similarity index estimation and UPGMA were done using the software package NTSYS-PC version 2.0 (Rohlf, 1997). The reliability of the UPGMA cluster was assessed by applying a bootstrap (1000 bootstraps) procedure (WINBOOT; Yap and Nelson, 1996). Gene diversity (Nei, 1973) was estimated at each AFLP locus by the software package POPGENE, version 1.32 (Yeh et al., 2004). Genotypic diversity was estimated by the software package Multilocus 1.3 (Agapow and Burt, 2001). The proportion of fixed recessive AFLP alleles for all the varieties was estimated according to Fu et al. (2002).

\section{Results}

Figure 1 shows a typical AFLP gel using the P74/M95 and $\mathrm{P} 101 / \mathrm{M} 95$ primer combinations on a series of 18 date palm varieties of Iraq. A total of 284 easily scorable bands were generated from seven selective AFLP primer combinations (Table 1). The number of amplified fragments per variety varied from 20 to 62 with an average of 40.6 fragments per primer combination. Among the 284 fragments scored across all the varieties, 162 bands $(58 \%)$ were conserved through all the varieties. The remaining $122(42 \%)$ were polymorphic for at least one of the varieties.

The ability of individual AFLP primer combinations to amplify polymorphic bands differed (Table 1). The primer combination P74/M95 amplified 40 polymorphic bands and the primer combination P109/M95 amplified only five. The selected seven AFLP primer combinations also differed with respect to their ability 


\section{3}
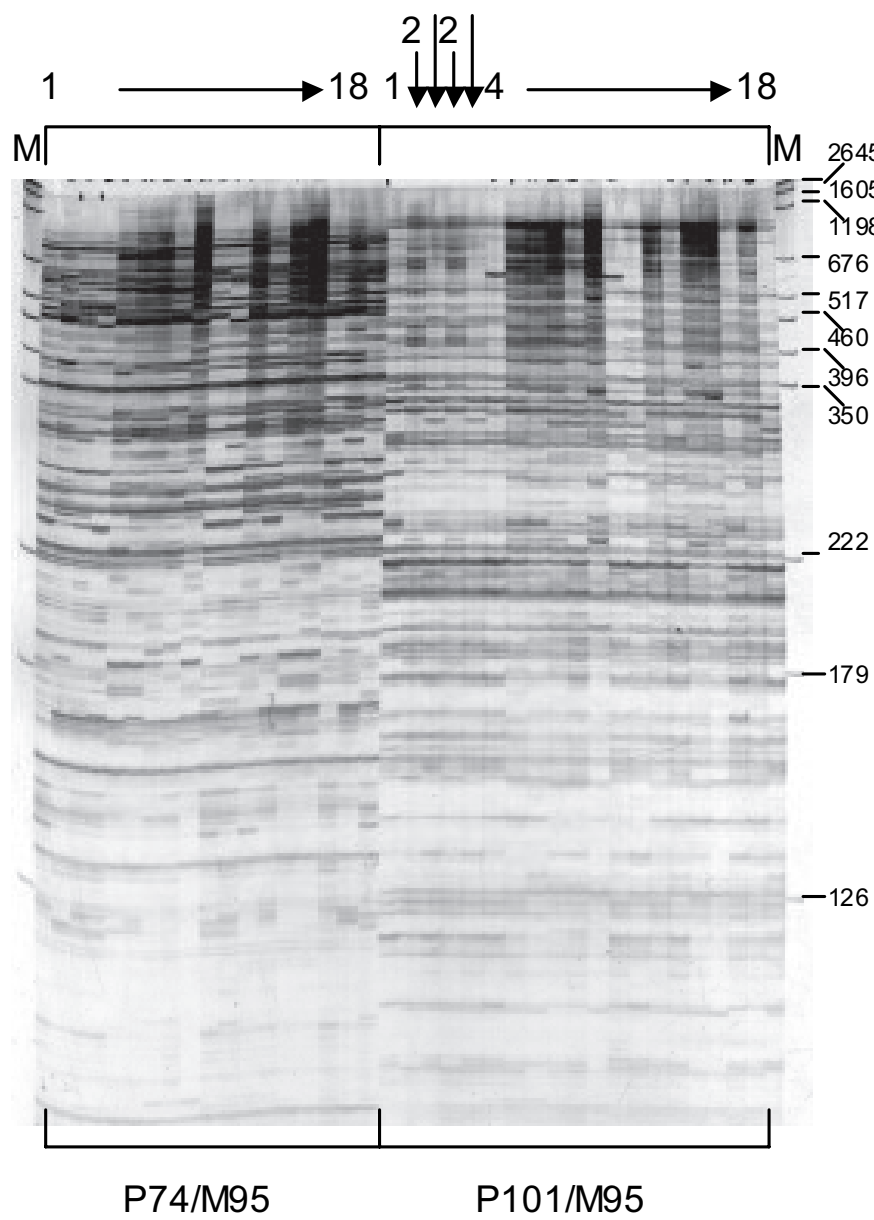

Fig. 1. AFLP banding pattern of the 18 date palm varieties of Iraq as revealed by primer combinations P74/M95 and P101/M95. Numbers on the right indicate the fragment size of molecular weight markers (lane $\mathrm{M}$ ) in base pairs (bp). The lanes 1 to 18 are the banding pattern of 'Barhi', 'Um Al-Dihen', 'Usta Umran', 'Maktom', 'Guntar', 'Khestawi', 'Zahdi', 'Sakri', 'Khedrawi', 'Chipchab', 'Ashrasi', 'Jamal Al-Dean', 'Shwethi Asfar', 'Zuber', 'BintAl-Suda', 'Bream', 'See Sandali', and 'Tebarzal', respectively. In order to test reproducibility, the AFLP analysis of 'Um Al-Dihen' (\#2) and 'Usta Umran' (\#3) were repeated and samples were loaded side by side. to distinguish the 18 date palm varieties. P73/M95, P74/M95, P100/M95, and P101/M95 distinguished all the 18 date palm varieties (genotypic diversity $=1.00$; Table 1 ), whereas the other three primer combinations P104/M95, P107/M107, and P109/M95 distinguished 17, 11, and seven date palm varieties, respectively.

The average Nei's gene diversity (Nei, 1973) detected by various primer combinations also varied (Table 2 ), and estimates ranged from 0.29 (P109/M95) to 0.39 (P107/M107) with overall average gene diversity of $0.36(\mathrm{SD}= \pm 0.14)$. The gene diversity estimates for each primer combination did not correlate with the number of amplified fragments $(r=0.17)$ or number of fragments per genotype $(r=0.05)$, indicating that the number of amplified fragments is not an indicator of discriminating ability of a primer combination.

The 122 polymorphic bands in the 18 date palm varieties appear to be either frequently (the band was present in 17 varieties) or rarely present in the varieties (the band was present in only one variety out of 18; Fig. 2). There was only one locus which amplified a common band in 17 varieties, 14 loci could amplify a band in 12 varieties and only four loci could amplify a band in one variety. The proportion of fixed recessive AFLP alleles for all the varieties ranged from $32 \%$ to $69 \%$ with a mean of $52.7 \%$ (Fig. 3).

The pair-wise Jaccard's genetic similarity index (Jaccard, 1908) was calculated for all 122 amplified polymorphic fragments (loci) of the 18 varieties (Table 2). The genetic similarity index among varieties varied from 0.108 to 0.756 , indicating diverse relationships. The variety 'Bint Al-Suda' is highly divergent from 'Ashrasi' and very closely related to 'Khedrawi'. UPGMA ordered the date palm varieties first into two broad groups at $27 \%$ similarity levels (Fig. 4). One group consists of seven varieties ('Barhi', 'Bream', 'Usta Umran', 'Maktom', 'Chipchab', 'Ashrasi', and 'Tebarzal') and the second group consisted of the remaining 11 varieties of date palm. The second group consists of two subgroups (at $46 \%$ similarity level), one with two varieties ('Um Al-Dihen' and 'Sakri') and the other with nine varieties ('Guntar', 'Khestawi', 'Zuber', 'Jamal Al-Dean', 'Khedrawi', 'Bint Al-Suda', 'Zahdi', 'Shwethi Asfar', and 'See Sandali').

\section{Discussion}

The success of any genetic conservation or breeding program is dependent on understanding the amount and distribution of the genetic variation present in the genetic pool. Morphological

Table 1. Number of fragments amplified, number of genotypes defined, gene and genotypic diversity estimated by AFLP markers in 18 date palm varieties of Iraq.

\begin{tabular}{|c|c|c|c|c|c|c|c|}
\hline $\begin{array}{l}\text { Primer } \\
\text { combinations }\end{array}$ & $\begin{array}{c}\text { Total } \\
\text { fragments (no.) }\end{array}$ & $\begin{array}{c}\text { Polymorphic } \\
\text { fragments (no.) }\end{array}$ & $\begin{array}{l}\text { Monomorphic } \\
\text { fragments (no.) }\end{array}$ & $\begin{array}{c}\text { Genotypes } \\
\text { defined (no.) }\end{array}$ & $\begin{array}{c}\text { Range of } \\
\text { gene diversity }\end{array}$ & $\begin{array}{l}\text { Avg gene } \\
\text { diversity }\end{array}$ & $\begin{array}{l}\text { Genotypic } \\
\text { diversity }\end{array}$ \\
\hline$\overline{\text { P101(aacg)/M95(aaaa) }}$ & 58 & 34 & 24 & 18 & $0.06-0.50$ & $0.37 \pm 0.14$ & 1.00 \\
\hline P74(ggt)/M95(аaаa) & 62 & 40 & 22 & 18 & $0.06-0.50$ & $0.35 \pm 0.30$ & 1.00 \\
\hline P104(aagc)/M95(aaaa) & 34 & 11 & 23 & 17 & $0.16-0.50$ & $0.38 \pm 0.10$ & 0.993 \\
\hline P73(ggg)/M95(aаaa) & 33 & 12 & 21 & 18 & $0.06-0.50$ & $0.36 \pm 0.15$ & 1.00 \\
\hline P100(aаcc)/M95(аaаa) & 33 & 13 & 20 & 18 & $0.11-0.50$ & $0.34 \pm 0.16$ & 1.00 \\
\hline P109(aatg)/M95(aaaa) & 20 & 5 & 15 & 7 & $0.11-0.50$ & $0.29 \pm 0.16$ & 0.797 \\
\hline P107(aata)/M307(aata) & 44 & 7 & 37 & 11 & $0.11-0.50$ & $0.39 \pm 0.14$ & 0.889 \\
\hline Overall & 284 & $122(42 \%)$ & $162(58 \%)$ & 18 & $0.06-0.50$ & $0.36 \pm 0.14$ & 1.00 \\
\hline
\end{tabular}



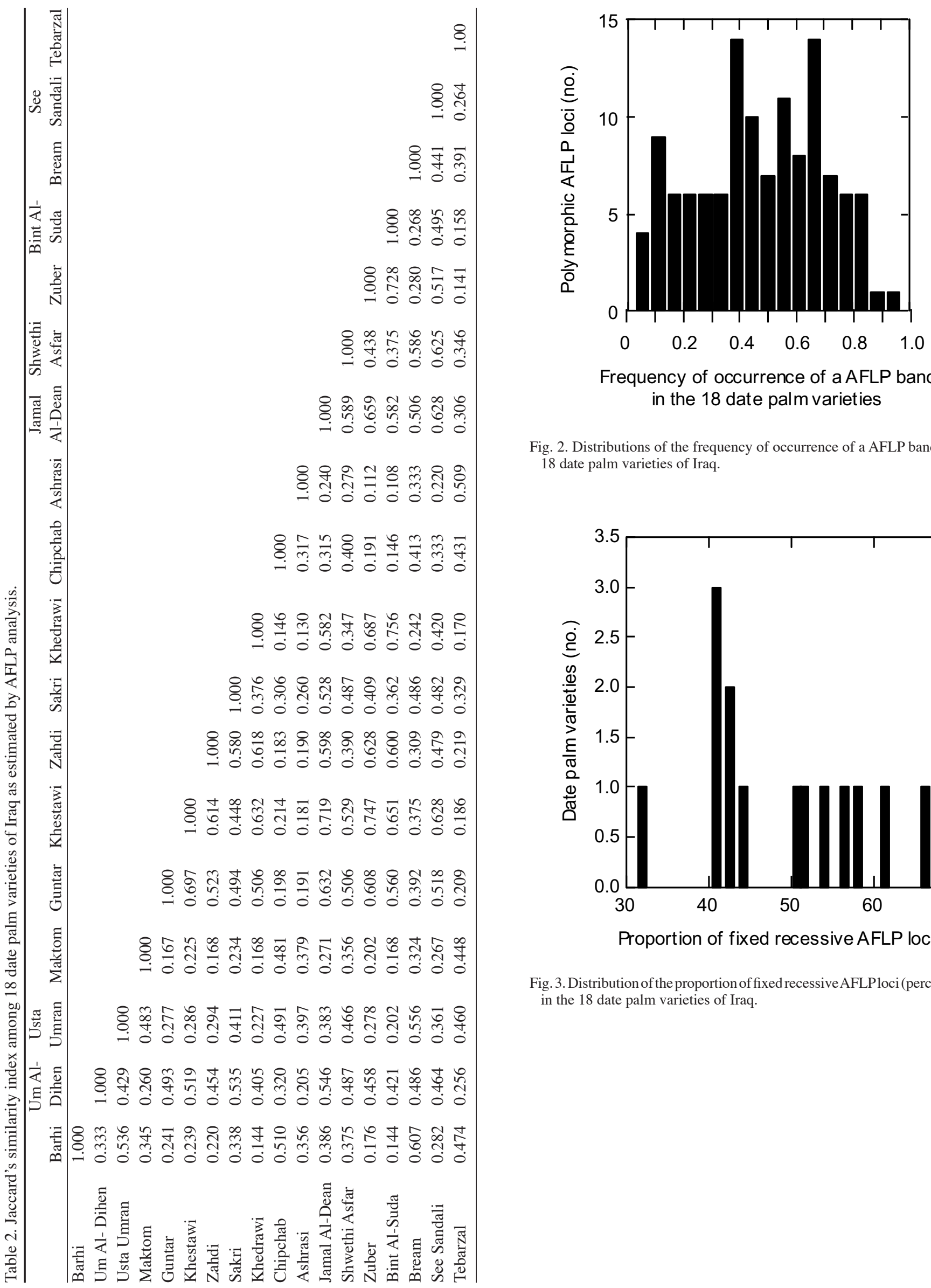

Frequency of occurrence of a AFLP band in the 18 date palm varieties

Fig. 2. Distributions of the frequency of occurrence of a AFLP band in the 18 date palm varieties of Iraq.

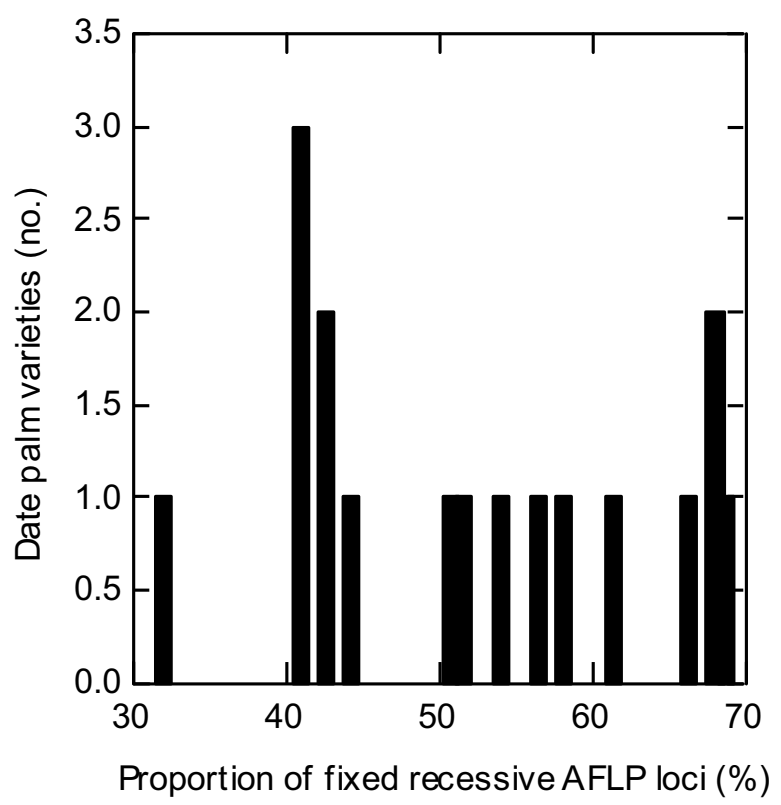

Fig. 3. Distribution of the proportion of fixed recessive AFLPloci (percentage) in the 18 date palm varieties of Iraq. 


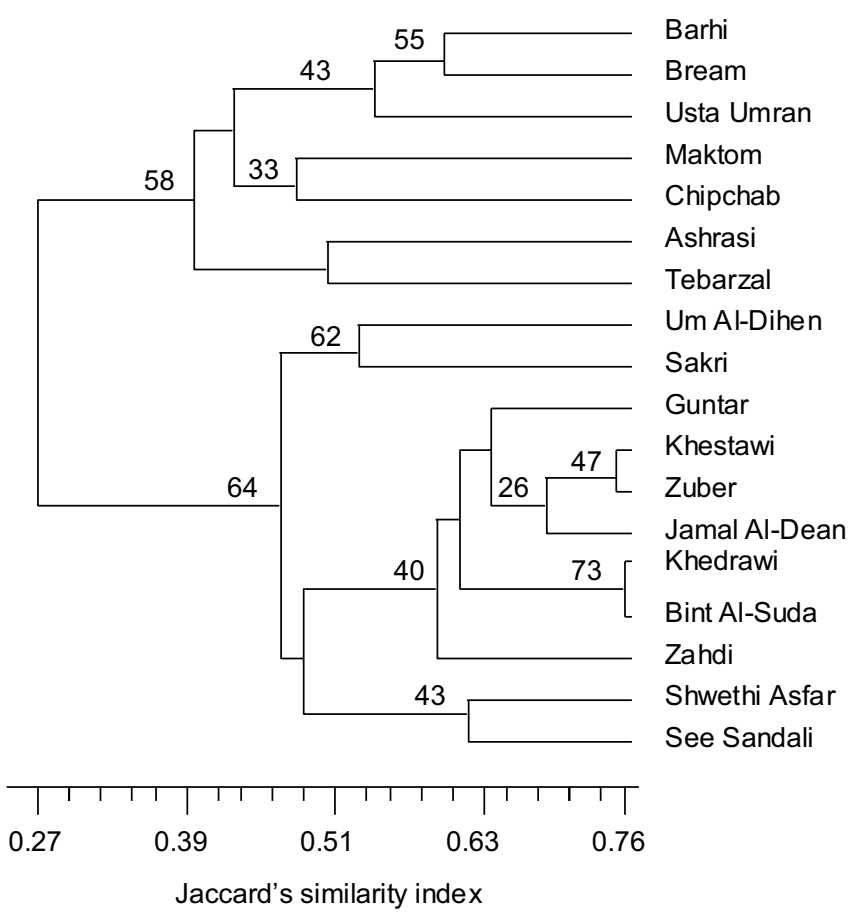

Fig. 4. Genetic relationships of 18 date palm varieties of Iraq as revealed by AFLP analysis. The values on the branches are the bootstrap probabilities (only values more than or equal to 25 are denoted).

traits are used to describe such genetic variation in date palm varieties (Askari et al., 2003; Barreveld, 1993; Bashah, 1996; Mohammed et al., 1983). These traits are mainly related to the fruit, and are complex and greatly influenced by the environment (Askari et al., 2003; Sedra et al., 1993, 1998). Identification and characterization of varieties based on these morphological traits alone is difficult and not necessarily accurate. A variety may have different names in different plantations and genetically different varieties may have the same name (Torres and Tisserat, 1980). Furthermore, identification and characterization of the varieties are usually not possible until the onset of fruits, which may take 3-5 years. Protein markers such as isozymes have been suggested as an alternative (Bennaceur et al., 1991), however, they are limited by their number, and are developmentally regulated and, in some cases, are also influenced by the environment.

There are several different DNA marker analysis techniques that have been used to identify and characterize crop plants to determine genetic diversity (Powell et al., 1996). Each technique has its own requirements, sensitivity, and reliability. AFLP technique has been reported to be useful for studying genetic variation in date palm (Cao and Chao, 2002; Devanand and Chao, 2003). Therefore, we selected AFLP technique to estimate genetic relationships among 18 varieties of date palm of Iraq.

In our study, AFLP technique reliably distinguished all the 18 varieties of date palm, indicating that all the varieties are genetically distinct and there are no multiple names for the same variety in Iraq. Polymorphism detection efficiency among Iraqi date palm varieties by AFLPs was very high compared to other marker systems, such as isozymes (Bennaceur et al., 1991), RFLPs (Corniquel and Mercier, 1994), and RAPDs (Al-Khalifah and Askari, 2003). Out of seven primer combinations used in the present study, four primer combinations were very effective in distinguishing date palm varieties when used individually. The high level of intervarietal polymorphism detected in this study could be partly due to the strong out-crossing mechanism in this species, which is likely to increase the degree of polymorphism, and partly due to the AFLP technique and the primer combinations used. Any one of these primer combinations, P73/M95, P74/M95, P100/M95, and P101/M95, could be used to identify or distinguish all the 18 varieties. In contrast, the screening of 140 RAPD primers allowed selection of only 37 polymorphic primers, which all together were able to distinguish 13 varieties of date palm from Saudi Arabia (Al-Khalifah and Askari, 2003). In general, the RAPD technique is less reproducible and, therefore, data obtained from RAPD analysis are less reliable than AFLP analysis (Powell et al., 1996).

To allow better understanding of the genetic changes in the genome of date palm varieties, average proportion of fixed recessive AFLP loci was estimated. Most of the loci in 'Chipchab' are fixed (fixed recessive AFLP loci $=69 \%$ ), whereas most of the loci could be heterozygous in 'Jamal Al-Dean' (fixed recessive AFLP loci $=32 \%$ ). The information on the proportion of fixed recessive AFLPloci along with the information on polymorphism will be very useful for selecting suitable parents for development of mapping and breeding populations.

Although these varieties have been grown in Iraq for many years, the genetic relatedness of them was unknown because of the difficulty in estimating the genetic distance based on phenotypic data, which are often influenced by the environment. AFLP analysis enabled us to estimate genetic relatedness. Genetic similarity coefficient and cluster analysis based on AFLP profiles have clearly distinguished all the 18 varieties of date palm with more than $25 \%$ bootstrap UPGMA searches. Therefore, no different vernacular names refer to the same variety in Iraq.

In conclusion, AFLP markers exhibited a high level of efficiency for detecting polymorphism among the date palm varieties of Iraq. AFLP markers can be efficiently used for the estimation of genetic diversity pattern and its distribution in natural date palm populations in Iraq, which may help in estimating genetic erosion in natural populations of date palm in Iraq. The available AFLP fingerprints may also be a good starting point to characterize wild date palm germplasm to be used for the breeding. The molecular characterization will also increase date palm genetic conservation and improvement efforts as a part of the efforts to rebuild war-torn Iraq. For further molecular characterization of natural date palm populations, in addition to AFLP markers, recently developed microsatellite markers (Billotte et al., 2004) could also be used as microsatellite markers are reported to be highly polymorphic in many plant species (Powell, 1996).

\section{Literature Cited}

Agapow, P-M. and A. Burt. 2001. Indices of multilocus linkage disequilibrium. Mol. Ecol. Notes 1:101-102.

Al-Khalifah, N.S. and E. Askari. 2003. Molecular phylogeny of date palm (Phoenix dactylifera L.) cultivars from Saudi Arabia by DNA fingerprinting. Theor. Appl. Genet. 107:1266-1270.

Askari, E., N.S. Al-Khalifah, T. Ohmura, Y.S. Al-Hafidh, F.A. Khan, A. Al-Hindi, and R. Okawara. 2003. Molecular phylogeny of seven date palm (Phoenix dactylifera L.) cultivars by DNA fingerprinting. Pakistan J. Bot. 35:323-330.

Bandelj, D., J. Jakše, and B. Javornik. 2004. Assessment of genetic variability of olive varieties by microsatellite and AFLP markers. Euphytica 136:93-102.

Barrett, B.A. and K.K. Kidwell. 1998. AFLP-based genetic diversity 
assessment among wheat cultivars from the Pacific Northwest. Crop Sci. 38:1261-1271.

Barreveld W.H. 1993. Date palm products. FAO Agr. Serv. Bul. No. 101. Food Agr. Org. of the United Nations, Rome.

Bashah, M.A. 1996. Date variety in the Kingdom of Saudi Arabia, p. 1225-1319. In: King Abdulaziz Univ. Guidance booklet palms and dates. King Abdulaziz Univ. Press, Riyadh, Saudi Arabia,

Bennaceur, M., C. Lanaud, M.H. Chevalier, and N. Bounagua. 1991. Genetic diversity of the date palm (Phoenix dactylifera L.) from Algeria revealed by enzyme markers. Plant Breeding 107:56 -69.

Billotte, N., N. Marseillac, P. Brottier, J.-L. Noyer, J.-P. JacquemoudCollet, C. Moreau, T. Couvreur, M.-H. Chevallier, J.-C. Pintaud, and A.-M. Risterucci. 2004. Nuclear microsatellite markers for the date palm (Phoenix dactylifera L.): Characterization and utility across the genus Phoenix and in other palm genera. Mol. Ecol. Notes 4:256.

Cao, B.R. and C. T. Chao. 2002. Identification of date palm cultivars in California using AFLP markers. HortScience 37:966-968.

Corniquel, B. and L. Mercier. 1994. Date palm (Phoenix dactylifera L.) cultivar identification by RFLP and RAPD. Plant Sci. 101:163-172.

Devanand, P.S. and C.T. Chao. 2003. Genetic variation within 'Medjool' and 'Deglet Noor' date (Phoenix dactylifera L.) cultivars in California detected by fluorescent-AFLP markers. J. Hort. Sci. Biotechnol. 78:405-409.

Fanizza, G., R. Chaabane, F. Lamaj, L. Ricciardi, and P. Resta. 2003. AFLP analysis of genetic relationships among aromatic grapevines (Vitis vinifera). Theor. Appl. Genet. 107:1043-1047.

Food and Agriculture Organization. 2004. Food and Agriculture Organization statistical databases (FAOSTAT), Food Agr. Org. of the United Nations, Rome. 24 May 2004. <http://faostat.fao.org/>.

Fu, Y.B.,A. Diederichsen, K.W. Richards, and G. Peterson. 2002. Genetic diversity of flax (Linum usitatissimum L.) cultivars and landraces as revealed by RAPDs. Genet. Res. Crop Evol. 49:167-174.

Herselman, L. 2003. Genetic variation among Southern African cultivated peanut (Arachis hypogaea L.) genotypes as revealed by AFLP analysis. Euphytica 133:319-327.

Jaccard, P. 1908. Nouvelles rescherches sur la distribution florale. Bulletin Société Vaudoise des Sciences Naturelles. 44:223-270.

Lin, J.J., J. Kuo, J. Ma, J.A. Saunders, H.S. Beard, M.H. MacDonald, W. Kenworthy, G.N. Ude and B.F. Matthews. 1996. Identification of molecular markers in soybean comparing RFLP, RAPD and AFLPDNA mapping techniques. Plant Mol. Biol. Rept. 14:156-169.
MacFarquhar, N. 2003. Forbidden fruit: Iraq dates hit by war and sanctions. Intl. Herald Tribune. 1 July 2004. < http://www.iht.com/ articles/83194.html>.

Mohammed, S., H.R. Shabana, and E.A. Mawlod. 1983. Evaluation and identification of Iraqi date cultivars: Fruit characteristics of fifty cultivars. Date Palm J. 2:27-55.

Nei, M. 1973. Analysis of gene diversity in subdivided populations. Proc. Natl. Acad. Sci. USA 70:3321-3323.

Powell, W., M. Morgante, C. Andre, M. Hanafey, J. Vogel, S. Tingey, and A. Rafalski. 1996. The comparison of RFLP, RAPD, AFLP, and SSR (microsatellite) markers for germplasm analysis. Mol. Breeding 2:225-238.

Rohlf, F.J. 1997. NTSYS-pc: Numerical taxonomy and multivariate analysis system (version 2.0). Exeter Software, Setauket, N.Y.

Sanchez, G.S., S. Restrepo, M. Duque, M. Fregene, M. Bonierbale, and V. Verdier. 1999. AFLP assessment of genetic variability in cassava accessions (Mahihot esculenta) resistant and susceptible to cassava bacterial blight (CBB). Genome 42:163-172.

Sedra, My.H., H. El-Filali, and D. Frira. 1993. Observations sur quelques caracteristiques phenotypiques et agronomiques du fruit des varietes et clones du palmier dattier selectionnes. Al-Awamia 82:105-120.

Sedra, My.H., P. Lashermes, P. Trouslot, M. Combes, and S. Hamon. 1998. Identification and genetic diversity analysis of date palm (Phoenix dactylifera L.) varieties of Morocco using RAPD markers. Euphytica 103:75-82.

Tohme, J., D.O. Gonzalez, S. Beebe, and M.C. Duque. 1996. AFLP analysis of gene pools of a wild bean core collection. Crop Sci. 36:1375-1384.

Torres, A.M. and B. Tisserat. 1980. Leaf isozymes as genetic markers in date palms. Amer. J. Bot. 67:162-167.

Vos, P., R. Hogers, M. Bleeker, M. Reijans, T. van de Lee, M. Hornes, A. Frijters, J. Pot, J. Peleman, M. Kuiper, and M. Zabeau. 1995. AFLP: A new technique for DNA fingerprinting. Nucleic Acids Res. 23:4407-4414.

Yap, I.V. and R. Nelson. 1996. WinBoot: A program for performing bootstrap analysis of binary data to determine the confidence limits of UPGMA-based dendrograms. Intl. Rice Res. Inst. Discussion Paper Ser. No. 14. Intl. Rice Res. Inst., Los Baños, Philippines.

Yeh, F.C., R. Yang, and T. Boyle. 2004. Official site of POPGENE, the user-friendly freeware for population genetic analysis, 1 July 2004. $<$ http://www.ualberta.ca/ fyeh $>$. 